ISSN 0258-7122 (Print), 2408-8293 (Online)

Bangladesh J. Agril. Res. 42(2): 249-258, June 2017

\title{
COMBINED EFFECT OF SULPHUR AND BORON ON YIELD AND YIELD CONTRIBUTING CHARACTERS, NUTRIENT AND OIL CONTENT OF MUSTARD
}

\author{
A. AZAM $^{1}$, M. M. RAHMAN ${ }^{2}$, M. SAMSUZZAMAN ${ }^{3}$ \\ M. A. MAIN ${ }^{4}$ AND M. A. QUDDUS ${ }^{5}$
}

\begin{abstract}
This experiment was conducted in the experimental field of Sher-e-Bangla Agricultural University, Dhaka during 2014-2015 to know the combined effect of different levels of sulphur (S) and boron (B) on yield and yield contributing characters, nutrient and oil content of mustard and to find out the suitable combination of sulphur (S) and boron (B) for yield maximization of mustard. There were 16 treatment combinations comprising four levels each of $S\left(S_{0}=0\right.$, $\mathrm{S}_{1}=10, \mathrm{~S}_{2}=20$ and $\left.\mathrm{S}_{3}=30 \mathrm{~kg} \mathrm{~S} \mathrm{ha}{ }^{-1}\right)$ and $\mathrm{B}\left(\mathrm{B}_{0}=0, \mathrm{~B}_{1}=1, \mathrm{~B}_{2}=2\right.$ and $\mathrm{B}_{3}=3 \mathrm{~kg} \mathrm{~B}$ $\left.\mathrm{ha}^{-1}\right)$. It was replicated thrice in a randomized complete block design. Results showed that the combination of $\mathrm{S}$ and $\mathrm{B}\left(20 \mathrm{~kg} \mathrm{~S} \mathrm{ha}^{-1}\right.$ and $\left.3 \mathrm{~kg} \mathrm{~B} \mathrm{ha}{ }^{-1}\right)$ contributed positively for better performance of yield contributing characters of mustard. The combination $\mathrm{S}_{2} \mathrm{~B}_{3}\left(20 \mathrm{~kg} \mathrm{~S}^{-1}\right.$ and $\left.3 \mathrm{~kg} \mathrm{~B} \mathrm{ha}^{-1}\right)$ produced the highest grain yield (2180 kg ha-1) followed by $\mathrm{S}_{3} \mathrm{~B}_{2}$ and $\mathrm{S}_{3} \mathrm{~B}_{3}$ treatment combination. The highest protein and oil content of mustard were recorded from $\mathrm{S}_{3} \mathrm{~B}_{3}\left(30 \mathrm{~kg} \mathrm{~S} \mathrm{ha} \mathrm{k}^{-1}\right.$ and $\left.3 \mathrm{~kg} \mathrm{~B} \mathrm{ha}{ }^{-1}\right)$ treatment followed by $\mathrm{S}_{2} \mathrm{~B}_{3}$ treatment combination. Therefore, the combination of $\mathrm{S}$ and $\mathrm{B}\left(20 \mathrm{~kg} \mathrm{~S} \mathrm{ha}^{-1}\right.$ and $3 \mathrm{~kg} \mathrm{~B} \mathrm{ha}^{-}$ $\left.{ }^{1}\right)$ might be suitable dose for cultivation of mustard in tejgaon series soils under agro-ecological zone of 28 (Madhupur Tract) Bangladesh.
\end{abstract}

Keywords: Mustard, sulfur and boron, oil and nutrient content, yield.

\section{Introduction}

Mustard (Brassica rapa) is one of the important oilseed crops grown in Bangladesh, covers almost $60 \%$ of the total oil seed demand. The annual production of mustard is 3.34 lakh metric tons from the area of 3.52 lac hectares against the total oilseed production of 5.48 lakh tons (BBS, 2011). Local production of mustard oil meets nearly $25 \%$ oil requirement of Bangladesh. The average seed yield of mustard is very low in Bangladesh compared to other countries due to inheritance, environmental and poor fertilizer management. However, Bangladesh Agricultural Research Institute has developed high yielding mustard varieties viz., BARI Sharisha-8, BARI Sharisha-9 and BARI Sharisha-11. Hence, high yielding varieties with appropriate fertilizer management can be increased the productivity of mustard in Bangladesh. In

${ }^{1}$ Student, SAU, Dhaka, ${ }^{2}$ Scientific Officer, PRSS, Bangladesh Agricultural Research Institute (BARI), Gazipur, ${ }^{3}$ Senior Officer, ABFL, Mymensingh, ${ }^{4}$ Scientific Officer, DATCL, Jessore, ${ }^{5}$ Senior Scientific Officer, HRC, BARI, Gazipur, Bangladesh. 
general, mustard is considered as sulphur (S) loving crop and is highly susceptible to $S$ deficiency and responds well to $S$ fertilization (Haque, 2000). Sulphur is greatly influenced the synthesis of amino acids (cystine, cysteine and methionine), co-enzymes (biotin, coenzyme A, pyrophosphate, lipoic acid and thiamine) and some secondary metabolites (FRG, 2012). It also helps in chlorophyll formation and enhances the vegetative growth. Sulphur played a vital role for yield maximization and oil content of mustard. It also influenced the oil quality of mustard by increasing protein content and some fatty acids (Aulakh and Pasricha, 1997). Moreover, S contributes the uptake of nitrogen $(\mathrm{N})$, phosphorous (P) and potassium (K). About $97 \%$ soils of Bangladesh are deficient in $\mathrm{S}$ due to use sulphur free fertilizer (Khan et al., 2008). Boron deficiency is another problem for cultivation of oil seed crops. More than one million hectares of land showed B deficiency which are caused lower yield of oil seeds (Khan et al., 2008; Islam et al., 1999). Among micronutrients- boron has taken third place due to total B concentration in seed and stem of oilseed crops (Robinson, 1973). Boron helps the assimilation of $\mathrm{N}, \mathrm{P}$ and $\mathrm{K}$ and rate of water adsorption and carbohydrate translocation in plant. It is extensively involved in the synthesis of protein and oil (Malewar et al., 2001). Thus, B deficiency affects the equilibrium state of N, P and K. Boron application markedly increases pod number and seed set. Seed yield of mustard increased from 16 to 69\% due to B application (Islam and Sarker, 1993).

Several researches have been carried out on the effect of N, P and K fertilizers on mustard and other oil seed crops. But a few research works have been done to know the effect of S and B on production of oil seed crops in Bangladesh. The above discussion suggests that the limiting nutrients need to be identified in order to increase the production and nutritional value of mustard. Keeping the above mentioned facts, the study was undertaken to compare the yield and yield contributing characters and quality performance of mustard by using different doses of $\mathrm{S}$ and $\mathrm{B}$ and to find out the optimum dose of $\mathrm{S}$ and $\mathrm{B}$ for achieving its maximum yield potential at Tejgaon series soil of Modhapur Tract.

\section{Materials and Method}

The experiment was conducted at the Central Farm of the Sher-e-Bangla Agricultural University, Dhaka during November 2014 to February 2015. Experimental site- Sher-e-Bangla Agricultural University, Dhaka $\left(90.2^{\circ} \mathrm{N}\right.$ latitude and $23.5^{\circ} \mathrm{E}$ altitude) lies at an elevation of $8.2 \mathrm{~m}$ above the sea level. The terrace soils of Dhaka belongs to Tejgaon series under the agro ecological zone Madhupur Tract and texture is silty loam. There were 16 treatment combinations comprising four levels each of $S\left(S_{0}=0, S_{1}=10, S_{2}=20\right.$ and $\left.S_{3}=30 \mathrm{~kg} \mathrm{~S} \mathrm{ha}^{-1}\right)$ and $B\left(B_{0}=0, B_{1}=1, B_{2}=2\right.$ and $\left.B_{3}=3 \mathrm{~kg} \mathrm{~B} \mathrm{ha}^{-1}\right)$. The treatments were $S_{0} B_{0}, S_{0} B_{1}$, $\mathrm{S}_{0} \mathrm{~B}_{2}, \mathrm{~S}_{0} \mathrm{~B}_{3}, \mathrm{~S}_{1} \mathrm{~B}_{0}, \mathrm{~S}_{1} \mathrm{~B}_{1}, \mathrm{~S}_{1} \mathrm{~B}_{2}, \mathrm{~S}_{1} \mathrm{~B}_{3}, \mathrm{~S}_{2} \mathrm{~B}_{0}, \mathrm{~S}_{2} \mathrm{~B}_{1}, \mathrm{~S}_{2} \mathrm{~B}_{2}, \mathrm{~S}_{2} \mathrm{~B}_{3}, \mathrm{~S}_{3} \mathrm{~B}_{0}, \mathrm{~S}_{3} \mathrm{~B}_{1}, \mathrm{~S}_{3} \mathrm{~B}_{2}$ and 
$\mathrm{S}_{3} \mathrm{~B}_{3}$. The blanket doses of $120 \mathrm{~kg}$ urea ha ${ }^{-1}, 145 \mathrm{~kg} \mathrm{TSP} \mathrm{ha}^{-1}, 45 \mathrm{~kg} \mathrm{MoP} \mathrm{ha}^{-1}$ and $5 \mathrm{~kg} \mathrm{Z}_{\mathrm{n}} \mathrm{SO}_{4} \mathrm{ha}^{-1}$ were used. Soil samples $(0-20 \mathrm{~cm})$ before initiation of the experiment was analyzed for soil pH (Jackson, 1973), organic matter (Nelson and Sommers, 1982), total N (Bremner and Mulvaney, 1982), exchangeable K (Pratt, 1965), available P (Olsen \& Sommers, 1982), available S (Fox et al., 1964) and available B (Page et al., 1982). The results of the soil properties are shown in Table 1.

Table 1. Soil properties of the experimental field

\begin{tabular}{|c|c|c|c|c|c|c|c|}
\hline \multirow[b]{2}{*}{ Location } & \multirow[b]{2}{*}{$\mathrm{pH}$} & \multirow{2}{*}{$\begin{array}{l}\mathrm{OM} \\
(\%)\end{array}$} & $\mathrm{K}$ & \multirow{2}{*}{$\begin{array}{c}\text { Total N } \\
(\%)\end{array}$} & $\mathrm{P}$ & $S$ & B \\
\hline & & & $\underset{\mathrm{g}^{-1}}{\text { meq. } 100}$ & & \multicolumn{3}{|c|}{$\mu \mathrm{g} \mathrm{g}^{-1}$} \\
\hline SAU, Dhaka & 5.8 & 0.78 & 0.10 & 0.038 & 17 & 20 & 0.16 \\
\hline $\begin{array}{c}\text { Critical level } \\
(\text { FRG, 2012) }\end{array}$ & - & - & 0.12 & 0.12 & 10 & 10 & 0.2 \\
\hline
\end{tabular}

The land was prepared thoroughly by country plough followed by laddering. The treatments were laid out in Randomized Complete Block Design (RCBD) with three replications. The unit plots size was $2 \mathrm{~m} \times 2.5 \mathrm{~m}$. Gypsum and boric acid were used as the sources of $\mathrm{S}$ and $\mathrm{B}$, respectively. The whole amount of triple super phosphate (TSP), muriate of potash (MoP), zinc sulphate and $50 \%$ of urea were incorporated into soil at the time of final land preparation. Gypsum and boric acid were applied as per treatment. The remaining urea was applied at 25 days after seed germination. Seeds of mustard (BARI Sharisha-9) were sown on the 7 November, 2014. The seed rate was $6 \mathrm{~kg} \mathrm{ha}^{-1}$. Weeding was done at 20 and 35 days after sowing. Insecticide Sumithion 50EC at the rate of $2 \mathrm{ml} \mathrm{L}^{-1}$ water was sprayed for controlling pod borer. Crop was harvested after maturity. Data on yield contributing characters were collected from randomly selected five plants in each plot excluding border plants. Data on yields $\left(\mathrm{kg} \mathrm{ha}^{-1}\right)$ were recorded from the whole plot technique. Harvest index (\%) was calculated. Ground stover and seed samples were digested with di-acid mixture $\left(\mathrm{HNO}_{3}\right.$ $\mathrm{HClO}_{4}$ ) (5: 1) as described by Piper (1966) for the determination- concentration of $\mathrm{N}$ (Micro-Kjeldahl method), $\mathrm{P}$ (spectrophotometer method), $\mathrm{K}$ (atomic absorption spectrophotometer method), $\mathrm{S}$ (turbidity method using $\mathrm{BaCl}_{2}$ by spectrophotometer) and B (spectrophotometer following azomethine-H method). Oil content of seed was determined by Soxhlet method and expressed in percentage (\%). Nitrogen content was determined by Kjeldahl method. Protein content was measured by estimating the $\mathrm{N}$ content and then multiplying the $\mathrm{N}$ value by 6.25 . Collected data were analyzed statistically with MSTATC programme and the mean difference was adjusted by Duncan's Multiple Range Test (Gomez and Gomez, 1984) at $5 \%$ level of probability. 


\section{Results and Discussion}

\section{Yields and yield contributing characters of mustard}

Combination of sulphur and boron were exhibited significant effect on yields and yield contributing characters of mustard (Table 2). The highest plant height $(166.3 \mathrm{~cm})$ was recorded from the treatment of $\mathrm{S}_{2} \mathrm{~B}_{3}\left(20 \mathrm{~kg} \mathrm{~S}^{-1}\right.$ and $3 \mathrm{~kg} \mathrm{~B}$ ha ${ }^{1}$ ), which was significantly different over others treatment combinations but statistically identical to $S_{3} B_{3}$ treatment. The lowest height $(125 \mathrm{~cm})$ was found in $\mathrm{S}_{0} \mathrm{~B}_{1}\left(0 \mathrm{~kg} \mathrm{~S} \mathrm{ha}^{-1}\right.$ and $\left.1 \mathrm{~kg} \mathrm{~B} \mathrm{ha}^{-1}\right)$ treatment. Result is in agreement with the findings of some researchers such as Mohiuddin (2007) reported that the maximum height of mustard plants $(93.0 \mathrm{~cm})$ under combined application of $\mathrm{N}$ $(80)+\mathrm{S}(24) \mathrm{kg} \mathrm{ha}^{-1}$. The shortest plant $(72.0 \mathrm{~cm})$ was noted under no application of $\mathrm{N}$ and S. Islam (2003) also observed that the highest plant height $(74.23 \mathrm{~cm})$ was recorded from the treatment of $30 \mathrm{~kg} \mathrm{~S}+20 \mathrm{~kg} \mathrm{Mg} \mathrm{ha}^{-1}$ and the lowest $(56.67 \mathrm{~cm})$ was from control treatment. Number of branches per plant was ranged from 4.08-5.25. The highest number of brunches per plant (5.25) was recorded from the treatment $S_{2} B_{3}$ whish was significantly different over the other treatment but statistically identical to $S_{3} B_{1}, S_{3} B_{2}, S_{3} B_{3}$ and $S_{2} B_{2}$ and lowest (4.08) was in $\mathrm{S}_{0} \mathrm{~B}_{0}$. In case of pod length and number of capsules per plant showed the similar trend of number of branches per plant (Table 2). These results are in agreement with the findings of Mohiuddin (2007) and Haq (2012).

The maximum number of seeds per capsule (15.9) was recorded from the combination of $\mathrm{S}_{2} \mathrm{~B}_{2}\left(20 \mathrm{~kg} \mathrm{~S}^{-1}\right.$ and $\left.2 \mathrm{~kg} \mathrm{~B} \mathrm{ha}^{-1}\right)$ which showed significantly variation with others treatment combinations but it was statistically similar to $\mathrm{S}_{2} \mathrm{~B}_{3}\left(20 \mathrm{~kg} \mathrm{~S} \mathrm{ha}^{-1}\right.$ and $\left.3 \mathrm{~kg} \mathrm{~B} \mathrm{ha}^{-1}\right)$ treatment. Lowest number of seeds per capsule (9.29) was found in control plot. The above result is supported by the observation of Singh et al. (2007); Mohiuddin, (2007). Islam (2003) reported the highest number seeds pod ${ }^{-1}$ (17.6) was found in the treatment of $30 \mathrm{~kg} \mathrm{~S}+20 \mathrm{~kg}$ $\mathrm{Mg} \mathrm{ha}^{-1}$ and lowest (12.42) was in control treatment.

The 1000 seed weight due to different treatment combination varied from 8.0$15.4 \mathrm{~g}$. The highest 1000 seed weight was obtained from the treatment $\mathrm{S}_{2} \mathrm{~B}_{3}$ followed by $S_{3} B_{2}$ and $S_{3} B_{3}$ treatment. The lowest 1000 seed weight was recorded from $\mathrm{S}_{0} \mathrm{~B}_{0}$ treatment. Karthikeyan and Shukla (2011) obtained the highest dry matter of mustard seed from $\mathrm{S}_{60} \mathrm{~B}_{2}$ treatment. Mohiuddin (2007) observed the highest weight of 1000 seed $(2.86 \mathrm{~g})$ from the treatment combination $\mathrm{N}_{2} \mathrm{~S}_{3}$ comprising of $80 \mathrm{~kg} \mathrm{~N} \mathrm{ha}^{-1}+24 \mathrm{~kg} \mathrm{~S} \mathrm{ha}^{-1}$ and the lowest $(1.60 \mathrm{~g})$ was recorded in $\mathrm{N}_{0} \mathrm{~S}_{0}$ treatment. Islam (2003) reported the highest 1000 -seed weight $(2.75 \mathrm{~g})$ from the treatment of $30 \mathrm{~kg} \mathrm{~S}+20 \mathrm{~kg} \mathrm{Mg} \mathrm{ha}{ }^{-1}$.

The grain yield of mustard was varied from $1806-2180 \mathrm{~kg} \mathrm{ha}^{-1}$ due to different treatment combinations. The highest grain yield was recorded from the treatment

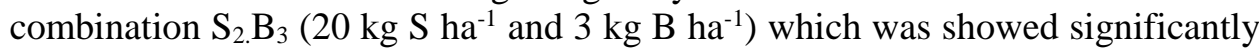
different among the treatments but statistically identical with $S_{3} B_{2}, S_{3} B_{0}$ and $S_{3} B_{3}$ treatments combination. The lowest yield was obtained from control $\left(\mathrm{S}_{0} \mathrm{~B}_{0}\right)$ 
treatment (Table 2). Karthikeyan and Shukla (2011) reported that highest yield seed $\left(20.6 \mathrm{~g} \mathrm{pot}^{-1}\right)$ was obtained from the treatment $S_{60} B_{2}\left(60 \mathrm{~g} \mathrm{~S} \mathrm{~kg}^{-1}\right.$ and $2 \mathrm{mg} \mathrm{B}$ $\left.\mathrm{kg}^{-1}\right)$. Mohiuddin (2007) also found the highest yield (1738 kg ha-1) from the treatment combination $\mathrm{N}_{2} \mathrm{~S}_{3}$ comprising of $80 \mathrm{~kg} \mathrm{~N} / \mathrm{ha}+24 \mathrm{~kg} \mathrm{~S} / \mathrm{ha}$ and the lowest $\left(850 \mathrm{~kg} \mathrm{ha}^{-1}\right)$ from $\mathrm{N}_{0} \mathrm{~S}_{0}$. Similar observation occurred by Islam (2003). The highest stover yield (2800 kg ha-1) found in treatment of S $30 \mathrm{~kg} \mathrm{ha}^{-1}$ and Boron $1 \mathrm{~kg} \mathrm{ha}^{-1}$ which was significantly different over the other treatment combinations and lowest $\left(2726 \mathrm{~kg} \mathrm{ha}^{-1}\right)$ in $\mathrm{S}_{0} \mathrm{~B}_{0}$ treatment. The result is in agreement with the findings of Mohiuddin (2007).

Harvesting index was positively influenced by different combinations of $\mathrm{S}$ and $\mathrm{B}$. The combined dose of $20 \mathrm{~kg} \mathrm{ha}^{-1} \mathrm{~S}$ and $3 \mathrm{~kg} \mathrm{ha}^{-1} \mathrm{~B}$ contributed significantly to get highest $(40.3 \%)$ harvest index of mustard and lowest harvest index (39\%) was calculated from the treatment of $\mathrm{S}_{0} \mathrm{~B}_{1}\left(0 \mathrm{~kg} \mathrm{~S} \mathrm{ha}^{-1}\right.$ and $\left.1 \mathrm{~kg} \mathrm{~B} \mathrm{ha}^{-1}\right)$ (Table 2).

Table 2. Combined effect of sulphur and boron on yield and yield contributing characters and harvest index $(\%)$ of mustard

\begin{tabular}{|c|c|c|c|c|c|c|c|c|c|}
\hline Treatment & $\begin{array}{c}\text { Plant } \\
\text { height } \\
(\mathrm{cm})\end{array}$ & $\begin{array}{c}\text { No. of } \\
\text { branches } \\
\text { plant }^{-1}\end{array}$ & $\begin{array}{c}\text { Pod } \\
\text { length } \\
(\mathrm{cm})\end{array}$ & $\begin{array}{c}\text { No. of } \\
\text { capsules } \\
\text { plant }^{-1}\end{array}$ & $\begin{array}{c}\text { No. of } \\
\text { seeds } \\
\text { capsule }^{-1}\end{array}$ & $\begin{array}{c}1000- \\
\text { seed } \\
\text { wt. } \\
(\mathrm{g})\end{array}$ & $\begin{array}{l}\text { Grain } \\
\text { yield } \\
(\mathrm{kg} \\
\left.\mathrm{ha}^{-1}\right)\end{array}$ & $\begin{array}{c}\text { Stover } \\
\text { yield } \\
(\mathrm{kg} \\
\left.\mathrm{ha}^{-1}\right)\end{array}$ & $\begin{array}{c}\text { Harvest } \\
\text { index } \\
(\%)\end{array}$ \\
\hline $\mathrm{S}_{0} \mathrm{~B}_{0}$ & $126.1^{\mathrm{g}}$ & $4.08^{\mathrm{d}}$ & $3.66^{\mathrm{d}}$ & $228^{f}$ & $9.29^{\mathrm{d}}$ & $8.0^{\mathrm{f}}$ & $1806^{\mathrm{h}}$ & $2726^{\mathrm{e}}$ & $39.1^{\mathrm{e}}$ \\
\hline $\mathrm{S}_{0} \mathrm{~B}_{1}$ & $125.0^{\mathrm{g}}$ & $4.29^{c}$ & $3.79^{c}$ & $230.2^{\mathrm{e}}$ & $9.34^{\mathrm{d}}$ & $9.2^{\mathrm{e}}$ & $1842^{\mathrm{fg}}$ & $2748^{\mathrm{d}}$ & $39^{f}$ \\
\hline $\mathrm{S}_{0} \mathrm{~B}_{2}$ & $131.3^{\mathrm{f}}$ & $4.42^{\mathrm{bc}}$ & $3.85^{b c}$ & $230.8^{\mathrm{e}}$ & $9.57^{\mathrm{d}}$ & $10.7^{\mathrm{cd}}$ & $1879^{f}$ & $2762^{c}$ & $39.6^{\mathrm{cd}}$ \\
\hline $\mathrm{S}_{0} \mathrm{~B}_{3}$ & $132.1^{\mathrm{ef}}$ & $4.61^{\mathrm{b}}$ & $3.89^{\mathrm{b}}$ & $234.3^{c}$ & $10.43^{\mathrm{cd}}$ & $11.5^{\mathrm{c}}$ & $2048^{c}$ & $2772^{b c}$ & $40^{\mathrm{b}}$ \\
\hline $\mathrm{S}_{1} \mathrm{~B}_{0}$ & $132.6^{\mathrm{ef}}$ & $4.46^{\mathrm{bc}}$ & $3.95^{\mathrm{b}}$ & $228.9^{f}$ & $9.38^{\mathrm{d}}$ & $10.8^{\mathrm{cd}}$ & $1925^{\mathrm{e}}$ & $2791^{\mathrm{b}}$ & $39.9^{b}$ \\
\hline $\mathrm{S}_{1} \mathrm{~B}_{1}$ & $138.5^{\mathrm{e}}$ & $4.51^{\mathrm{b}}$ & $4.04^{\mathrm{ab}}$ & $230.5^{\mathrm{e}}$ & $10.82^{\mathrm{cd}}$ & $9.3^{\mathrm{e}}$ & $1992^{\mathrm{d}}$ & $2745^{\mathrm{d}}$ & $39.5^{\mathrm{d}}$ \\
\hline $\mathrm{S}_{1} \mathrm{~B}_{2}$ & $141.3^{\mathrm{d}}$ & $4.49^{b c}$ & $4.12^{\mathrm{ab}}$ & $232.6^{\mathrm{d}}$ & $11.48^{\mathrm{c}}$ & $10^{\mathrm{d}}$ & $1984^{\mathrm{d}}$ & $2760^{\mathrm{cd}}$ & $39.8^{\mathrm{bc}}$ \\
\hline $\mathrm{S}_{1} \mathrm{~B}_{3}$ & $139.4^{\mathrm{e}}$ & $4.56^{\mathrm{b}}$ & $4.16^{\mathrm{a}}$ & $235.5^{\mathrm{c}}$ & $11.48^{\mathrm{c}}$ & $10.4^{\mathrm{d}}$ & $2037^{\mathrm{cd}}$ & $2777^{\mathrm{bc}}$ & $39.8^{\mathrm{bc}}$ \\
\hline $\mathrm{S}_{2} \mathrm{~B}_{0}$ & $138.9^{\mathrm{e}}$ & $4.43^{b c}$ & $4.08^{\mathrm{ab}}$ & $237.4^{\mathrm{b}}$ & $10.43^{\mathrm{cd}}$ & $10.9^{\mathrm{cd}}$ & $1939^{\text {de }}$ & $2781^{\mathrm{b}}$ & $40.1^{\mathrm{ab}}$ \\
\hline $\mathrm{S}_{2} \mathrm{~B}_{1}$ & $145.1^{\mathrm{cd}}$ & $4.6^{\mathrm{b}}$ & $4.15^{\mathrm{a}}$ & $238^{\mathrm{b}}$ & $12.32^{b c}$ & $11.7^{\mathrm{c}}$ & $1925^{\mathrm{e}}$ & $2769^{c}$ & $39.4^{\mathrm{de}}$ \\
\hline $\mathrm{S}_{2} \mathrm{~B}_{2}$ & $154.5^{\mathrm{b}}$ & $5.01^{\mathrm{ab}}$ & $4.2^{\mathrm{a}}$ & $238.4^{\mathrm{b}}$ & $15.9^{\mathrm{a}}$ & $13.3^{b}$ & $2050^{c}$ & $2763^{c}$ & $39.9^{\mathrm{b}}$ \\
\hline $\mathrm{S}_{2} \mathrm{~B}_{3}$ & $166.3^{\mathrm{a}}$ & $5.25^{\mathrm{a}}$ & $4.19^{a}$ & $241.3^{\mathrm{a}}$ & $15.75^{\mathrm{a}}$ & $15.4^{\mathrm{a}}$ & $2180^{\mathrm{a}}$ & $2747^{\mathrm{d}}$ & $40.3^{\mathrm{a}}$ \\
\hline $\mathrm{S}_{3} \mathrm{~B}_{0}$ & $145.1^{\mathrm{cd}}$ & $5.11^{\mathrm{ab}}$ & $4.17^{\mathrm{a}}$ & $237^{\mathrm{b}}$ & $10.35^{\mathrm{cd}}$ & $12.8^{b c}$ & $2170^{\mathrm{a}}$ & $2779^{b c}$ & $40.1^{\mathrm{ab}}$ \\
\hline$S_{3} B_{1}$ & $147.9^{c}$ & $5.21^{\mathrm{a}}$ & $4.16^{\mathrm{a}}$ & $239.8^{\mathrm{ab}}$ & $12.14^{\mathrm{bc}}$ & $13.6^{\mathrm{b}}$ & $2140^{\mathrm{b}}$ & $2800^{\mathrm{a}}$ & $39.7^{\mathrm{c}}$ \\
\hline $\mathrm{S}_{3} \mathrm{~B}_{2}$ & $148.7^{\mathrm{c}}$ & $5.17^{\mathrm{a}}$ & $4.17^{\mathrm{a}}$ & $241^{\mathrm{a}}$ & $13.63^{\mathrm{b}}$ & $14^{\mathrm{ab}}$ & $2170^{\mathrm{a}}$ & $2752^{\mathrm{cd}}$ & $39.6^{\mathrm{cd}}$ \\
\hline $\mathrm{S}_{3} \mathrm{~B}_{3}$ & $152.9^{\mathrm{ab}}$ & $5.08^{\mathrm{ab}}$ & $4.19^{a}$ & $240^{\mathrm{ab}}$ & $13.5^{\mathrm{b}}$ & $14.5^{\mathrm{a}}$ & $2150^{\mathrm{ab}}$ & $2761^{\mathrm{c}}$ & $39.3^{\mathrm{e}}$ \\
\hline $\begin{array}{c}\text { Level of } \\
\text { significance }\end{array}$ & $*$ & $*$ & $*$ & $*$ & $*$ & $*$ & $*$ & $*$ & $*$ \\
\hline
\end{tabular}

Mean value within the column with different superscripts are significantly different by DMRT.

$\mathrm{S}_{0} \mathrm{~B}_{0}=$ control; $\mathrm{S}_{0} \mathrm{~B}_{1}=0 \mathrm{~kg} \mathrm{~S}$ and $1 \mathrm{~kg} \mathrm{~B} ; \mathrm{S}_{0} \mathrm{~B}_{2}=0 \mathrm{~kg} \mathrm{~S}$ and $2 \mathrm{~kg} \mathrm{~B} ; \mathrm{S}_{0} \mathrm{~B}_{3}=0 \mathrm{~kg} \mathrm{~S}$ and $3 \mathrm{~kg}$ $\mathrm{B} ; \mathrm{S}_{1} \mathrm{~B}_{0}=10 \mathrm{~kg} \mathrm{~S}$ and $0 \mathrm{~kg} \mathrm{~B} ; \mathrm{S}_{1} \mathrm{~B}_{1}=10 \mathrm{~kg} \mathrm{~S}$ and $1 \mathrm{~kg} \mathrm{~B} ; \mathrm{S}_{1} \mathrm{~B}_{2}=10 \mathrm{~kg} \mathrm{~S}$ and $2 \mathrm{~kg} \mathrm{~B}$; $\mathrm{S}_{1} \mathrm{~B}_{3}=10 \mathrm{~kg} \mathrm{~S}$ and $3 \mathrm{~kg} \mathrm{~B} ; \mathrm{S}_{2} \mathrm{~B}_{0}=20 \mathrm{~kg} \mathrm{~S}$ and $0 \mathrm{~kg} \mathrm{~B} ; \mathrm{S}_{2} \mathrm{~B}_{1}=20 \mathrm{~kg} \mathrm{~S}$ and $1 \mathrm{~kg} \mathrm{~B} ; \mathrm{S}_{2} \mathrm{~B}_{2}=$ $20 \mathrm{~kg} \mathrm{~S}$ and $2 \mathrm{~kg} \mathrm{~B} ; \mathrm{S}_{2} \mathrm{~B}_{3}=20 \mathrm{~kg} \mathrm{~S}$ and $3 \mathrm{~kg} \mathrm{~B} ; \mathrm{S}_{3} \mathrm{~B}_{0}=30 \mathrm{~kg} \mathrm{~S}$ and $0 \mathrm{~kg} \mathrm{~B} ; \mathrm{S}_{3} \mathrm{~B}_{1}=30 \mathrm{~kg} \mathrm{~S}$ and $1 \mathrm{~kg} \mathrm{~B} ; \mathrm{S}_{3} \mathrm{~B}_{2}=30 \mathrm{~kg} \mathrm{~S}$ and $2 \mathrm{~kg} \mathrm{~B} ; \mathrm{S}_{3} \mathrm{~B}_{3}=30 \mathrm{~kg} \mathrm{~S}$ and $3 \mathrm{~kg} \mathrm{~B}$. 


\section{Nutrient content in stover and seed of mustard}

Different combinations of sulphur and boron were influenced significantly the nutrient (N, P, K, S and B) contents in stover and seed of mustard (Table 3). A range of $\mathrm{N}$ content $1.2-1.51 \%$ and $3.41-3.69 \%$ respectively were observed in stover and seed. The highest $\mathrm{N}$ content was found in $\mathrm{S}_{2} \mathrm{~B}_{3}$ treatment $\left(20 \mathrm{~kg} \mathrm{~S} \mathrm{ha}{ }^{-1}\right.$ and $3 \mathrm{~kg} \mathrm{~B} \mathrm{ha}^{-1}$ ) followed by $S_{2} B_{2}, S_{2} B_{3}, S_{3} B_{1}, S_{3} B_{2} \& S_{3} B_{3}$ and the lowest in control plot. In case of other nutrient content varied from $0.21-0.44 \% \mathrm{P}, 2.41$ $2.68 \% \mathrm{~K}, 0.08-0.88 \% \mathrm{~S}$ and $42.11-46.89 \mathrm{ppm} \mathrm{B}$ in stover and it were ranged from $0.45-0.57 \% \mathrm{P}, 1.09-1.38 \% \mathrm{~K}, 0.52-0.79 \% \mathrm{~S}$ and $47.67-59.89 \mathrm{ppm} \mathrm{B}$ in seed of mustard (Table 3 ). The content of $\mathrm{P}, \mathrm{K}, \mathrm{S}$ and $\mathrm{B}$ due to different combinations of sulphur and boron followed almost the same trend of $\mathrm{N}$ content (Table 3). The result is in agreement with the results of Karthikeyan and Shukla (2008); Ganesharmurthy (1996), Chand et al. (1997) and Sarker et al. (2002).

Table 3. Combined effect of sulphur and boron on nutrient contents in stover and seed of mustard

\begin{tabular}{|c|c|c|c|c|c|c|c|c|c|c|}
\hline \multirow{2}{*}{ Treatment } & \multicolumn{2}{|c|}{ Nitrogen $(\%)$} & \multicolumn{2}{|c|}{ Phosphorous (\%) } & \multicolumn{2}{|c|}{ Potassium (\%) } & \multicolumn{2}{|c|}{ Sulphur (\%) } & \multicolumn{2}{|c|}{ Boron(ppm) } \\
\hline & Stover & Seed & Stover & Seed & Stover & Seed & Stover & Seed & Stover & Seed \\
\hline & $1.20^{\mathrm{d}}$ & $3.41^{\mathrm{cd}}$ & & $45^{b}$ & $2.41^{\mathrm{cd}}$ & $1.09^{c}$ & $0.08^{\mathrm{d}}$ & $0.52^{\mathrm{cd}}$ & $42.11^{\mathrm{f}}$ & \\
\hline & d & $3.43^{\mathrm{cd}}$ & $21^{\mathrm{d}}$ & $46^{\mathrm{b}}$ & $2.43^{\mathrm{c}}$ & $1.09^{c}$ & $0.11^{\mathrm{cd}}$ & $0.57^{\mathrm{c}}$ & $42.38^{1-1}$ & \\
\hline & $6^{\mathrm{cd}}$ & $3.43^{\mathrm{cd}}$ & $24^{\mathrm{cd}}$ & $46^{\mathrm{b}}$ & $2.44^{\mathrm{c}}$ & $1.10^{\mathrm{c}}$ & $0.12^{\mathrm{cd}}$ & $0.57^{\mathrm{c}}$ & $42.67^{\mathrm{e}}$ & $47.99^{1}$ \\
\hline & & $3.45^{\mathrm{c}}$ & 0.26 & $47^{\mathrm{b}}$ & $2.47^{\mathrm{c}}$ & $1.11^{\mathrm{c}}$ & $0.13^{\mathrm{cd}}$ & $0.61^{\mathrm{bc}}$ & $42.99^{\mathrm{e}}$ & $48.46^{\mathrm{f}}$ \\
\hline & 1. & $3.44^{\mathrm{c}}$ & & $6^{\mathrm{b}}$ & & & $0.14^{\mathrm{c}}$ & $0.63^{\mathrm{bc}}$ & $43.18^{\mathrm{d}}$ & \\
\hline & & $3.48^{\mathrm{c}}$ & & $46^{\mathrm{b}}$ & & $1.14^{\mathrm{c}}$ & $0.15^{\mathrm{c}}$ & $0.67^{\mathrm{b}}$ & $43.23^{\mathrm{d}}$ & $0.12^{\mathrm{de}}$ \\
\hline & & $3.53^{\mathrm{b}}$ & & & & $1.17^{\mathrm{c}}$ & $0.16^{\mathrm{c}}$ & $0.67^{\mathrm{b}}$ & 43.3 & \\
\hline & & $3.55^{\mathrm{b}}$ & & & 2.5 & $1.23^{\mathrm{b}}$ & $0.17^{\mathrm{c}}$ & $0.67^{\mathrm{b}}$ & 43.8 & \\
\hline & & $3.48^{\mathrm{c}}$ & & & $2.58^{\mathrm{b}}$ & $1.25^{\mathrm{ab}}$ & $0.18^{\mathrm{c}}$ & $0.68^{\mathrm{b}}$ & $43.97^{\mathrm{cd}}$ & $52.89^{d}$ \\
\hline & 1.41 & $3.56^{\mathrm{b}}$ & & & 2.6 & $1.29^{\mathrm{ab}}$ & $0.24^{\mathrm{b}}$ & $0.71^{\mathrm{ab}}$ & $44.89^{c}$ & \\
\hline & & $3.59^{\mathrm{ab}}$ & & & 2.6 & $1.34^{\mathrm{a}}$ & $0.29^{\mathrm{ab}}$ & $0.72^{\mathrm{ab}}$ & 45.6 & \\
\hline & & 3.6 & & & & 1.3 & $0.38^{\mathrm{a}}$ & $0.79^{a}$ & 46.8 & \\
\hline & ab & $3.63^{\mathrm{ab}}$ & & & & $1.35^{\mathrm{a}}$ & $0.33^{\mathrm{ab}}$ & $0.76^{\mathrm{a}}$ & $46.46^{\mathrm{ab}}$ & $59.18^{b}$ \\
\hline & & 3.6 & & & & & & $0.79^{\mathrm{a}}$ & 46.6 & \\
\hline & & & & & & & $0.36^{\mathrm{a}}$ & $0.78^{\mathrm{a}}$ & $46.78^{\mathrm{a}}$ & \\
\hline & $1.49^{\mathrm{a}}$ & $3.69^{\mathrm{a}}$ & $0.44^{\mathrm{a}}$ & $0.56^{\mathrm{a}}$ & $2.68^{\mathrm{a}}$ & $1.38^{\mathrm{a}}$ & $0.36^{\mathrm{a}}$ & $0.78^{\mathrm{a}}$ & $46.87^{\mathrm{a}}$ & $59.98^{\mathrm{a}}$ \\
\hline
\end{tabular}

Mean value within the column with different superscripts are significantly different by DMRT.

$\mathrm{S}_{0} \mathrm{~B}_{0}=$ control; $\mathrm{S}_{0} \mathrm{~B}_{1}=0 \mathrm{~kg} \mathrm{~S}$ and $1 \mathrm{~kg} \mathrm{~B} ; \mathrm{S}_{0} \mathrm{~B}_{2}=0 \mathrm{~kg} \mathrm{~S}$ and $2 \mathrm{~kg} \mathrm{~B} ; \mathrm{S}_{0} \mathrm{~B}_{3}=0 \mathrm{~kg} \mathrm{~S}$ and $3 \mathrm{~kg}$ $\mathrm{B} ; \mathrm{S}_{1} \mathrm{~B}_{0}=10 \mathrm{~kg} \mathrm{~S}$ and $0 \mathrm{~kg} \mathrm{~B} ; \mathrm{S}_{1} \mathrm{~B}_{1}=10 \mathrm{~kg} \mathrm{~S}$ and $1 \mathrm{~kg} \mathrm{~B} ; \mathrm{S}_{1} \mathrm{~B}_{2}=10 \mathrm{~kg} \mathrm{~S}$ and $2 \mathrm{~kg} \mathrm{~B}$; $\mathrm{S}_{1} \mathrm{~B}_{3}=10 \mathrm{~kg} \mathrm{~S}$ and $3 \mathrm{~kg} \mathrm{~B} ; \mathrm{S}_{2} \mathrm{~B}_{0}=20 \mathrm{~kg} \mathrm{~S}$ and $0 \mathrm{~kg} \mathrm{~B} ; \mathrm{S}_{2} \mathrm{~B}_{1}=20 \mathrm{~kg} \mathrm{~S}$ and $1 \mathrm{~kg} \mathrm{~B} ; \mathrm{S}_{2} \mathrm{~B}_{2}=$ $20 \mathrm{~kg} \mathrm{~S}$ and $2 \mathrm{~kg} \mathrm{~B} ; \mathrm{S}_{2} \mathrm{~B}_{3}=20 \mathrm{~kg} \mathrm{~S}$ and $3 \mathrm{~kg} \mathrm{~B} ; \mathrm{S}_{3} \mathrm{~B}_{0}=30 \mathrm{~kg} \mathrm{~S}$ and $0 \mathrm{~kg} \mathrm{~B} ; \mathrm{S}_{3} \mathrm{~B}_{1}=30 \mathrm{~kg} \mathrm{~S}$ and $1 \mathrm{~kg} \mathrm{~B} ; \mathrm{S}_{3} \mathrm{~B}_{2}=30 \mathrm{~kg} \mathrm{~S}$ and $2 \mathrm{~kg} \mathrm{~B} ; \mathrm{S}_{3} \mathrm{~B}_{3}=30 \mathrm{~kg} \mathrm{~S}$ and $3 \mathrm{~kg} \mathrm{~B}$.

Combined effect of sulphur and boron on protein and oil content in mustard

Protein content in stover and seed of mustard was significantly affected by the treatment combination of S and B (Table 4). The highest protein content $(9.44 \%)$ 
in stover and (23.06\%) in seed were found in $\mathrm{S}_{2} \mathrm{~B}_{3}$ treatment $\left(20 \mathrm{~kg} \mathrm{~S}^{-1}\right.$ and 3 $\mathrm{kg} \mathrm{B} \mathrm{ha}{ }^{-1}$ ) which showed significant variation over the others treatment combination, but statistically similar to $S_{3} B_{3}$ in stover and $S_{3} B_{3} \& S_{3} B_{2}$ in seed. The lowest protein content (7.50\% in stover and $21.31 \%$ in seed) was observed in control treatment. This result is in agreement with the observation of Brady (1996). Similar finding was also corroborated by Tomar et al. (1996) who recorded the highest amount of protein in increasing S fertilization. Verma et al. (2002) reported the higher amount of protein was obtained from the combination of S $60 \mathrm{~kg} \mathrm{ha}^{-1}+\mathrm{B} 1.0 \mathrm{kgha}^{-1}$ followed by S $40 \mathrm{~kg} \mathrm{ha}^{-1}+\mathrm{B} 1.0 \mathrm{~kg} \mathrm{ha}^{-1}$.

Table 4. Combined effect of sulphur and boron on protein content in stover and seed \& oil content in seed of mustard

\begin{tabular}{l|cccc}
\hline \multirow{2}{*}{ Treatment } & \multicolumn{2}{|c|}{ Protein $(\%)$} & Oil content $(\%)$ \\
\cline { 2 - 4 } & Stover & Seed & seed \\
\hline $\mathrm{S}_{0} \mathrm{~B}_{0}$ & $7.50^{\mathrm{i}}$ & $21.31^{\mathrm{g}}$ & $41.67^{\mathrm{d}}$ \\
$\mathrm{S}_{0} \mathrm{~B}_{1}$ & $7.62^{\mathrm{h}}$ & $21.44^{\mathrm{f}}$ & $41.69^{\mathrm{d}}$ \\
$\mathrm{S}_{0} \mathrm{~B}_{2}$ & $7.87^{\mathrm{g}}$ & $21.44^{\mathrm{f}}$ & $41.83^{\mathrm{c}}$ \\
$\mathrm{S}_{0} \mathrm{~B}_{3}$ & $8.06^{\mathrm{f}}$ & $21.56^{\mathrm{ef}}$ & $41.88^{\mathrm{c}}$ \\
$\mathrm{S}_{1} \mathrm{~B}_{0}$ & $7.69^{\mathrm{h}}$ & $21.5^{\mathrm{ef}}$ & $42.87^{\mathrm{bc}}$ \\
$\mathrm{S}_{1} \mathrm{~B}_{1}$ & $8.19^{\mathrm{de}}$ & $21.75^{\mathrm{e}}$ & $42.88^{\mathrm{bc}}$ \\
$\mathrm{S}_{1} \mathrm{~B}_{2}$ & $8.37^{\mathrm{de}}$ & $22.06^{\mathrm{d}}$ & $42.97^{\mathrm{b}}$ \\
$\mathrm{S}_{1} \mathrm{~B}_{3}$ & $8.56^{\mathrm{d}}$ & $22.19^{\mathrm{cd}}$ & $43.01^{\mathrm{b}}$ \\
$\mathrm{S}_{2} \mathrm{~B}_{0}$ & $8.19^{\mathrm{de}}$ & $21.75^{\mathrm{e}}$ & $43.73^{\mathrm{b}}$ \\
$\mathrm{S}_{2} \mathrm{~B}_{1}$ & $8.81^{\mathrm{c}}$ & $22.25^{\mathrm{cd}}$ & $43.75^{\mathrm{b}}$ \\
$\mathrm{S}_{2} \mathrm{~B}_{2}$ & $9.00^{\mathrm{bc}}$ & $22.44^{\mathrm{c}}$ & $43.78^{\mathrm{b}}$ \\
$\mathrm{S}_{2} \mathrm{~B}_{3}$ & $9.44^{\mathrm{a}}$ & $23.06^{\mathrm{a}}$ & $43.80^{\mathrm{b}}$ \\
$\mathrm{S}_{3} \mathrm{~B}_{0}$ & $8.75^{\mathrm{d}}$ & $22.69^{\mathrm{b}}$ & $44.90^{\mathrm{a}}$ \\
$\mathrm{S}_{3} \mathrm{~B}_{1}$ & $9.06^{\mathrm{b}}$ & $22.69^{\mathrm{b}}$ & $44.93^{\mathrm{a}}$ \\
$\mathrm{S}_{3} \mathrm{~B}_{2}$ & $9.12^{\mathrm{b}}$ & $22.81^{\mathrm{ab}}$ & $44.95^{\mathrm{a}}$ \\
$\mathrm{S}_{3} \mathrm{~B}_{3}$ & $9.31^{\mathrm{ab}}$ & $23.06^{\mathrm{a}}$ & $44.98^{\mathrm{a}}$ \\
\hline
\end{tabular}

Mean value within the column with different superscripts are significantly different by DMRT.

$\mathrm{S}_{0} \mathrm{~B}_{0}=$ control; $\mathrm{S}_{0} \mathrm{~B}_{1}=0 \mathrm{~kg} \mathrm{~S}$ and $1 \mathrm{~kg} \mathrm{~B} ; \mathrm{S}_{0} \mathrm{~B}_{2}=0 \mathrm{~kg} \mathrm{~S}$ and $2 \mathrm{~kg} \mathrm{~B} ; \mathrm{S}_{0} \mathrm{~B}_{3}=0 \mathrm{~kg} \mathrm{~S}$ and $3 \mathrm{~kg}$ $\mathrm{B} ; \mathrm{S}_{1} \mathrm{~B}_{0}=10 \mathrm{~kg} \mathrm{~S}$ and $0 \mathrm{~kg} \mathrm{~B} ; \mathrm{S}_{1} \mathrm{~B}_{1}=10 \mathrm{~kg} \mathrm{~S}$ and $1 \mathrm{~kg} \mathrm{~B} ; \mathrm{S}_{1} \mathrm{~B}_{2}=10 \mathrm{~kg} \mathrm{~S}$ and $2 \mathrm{~kg} \mathrm{~B}$; $\mathrm{S}_{1} \mathrm{~B}_{3}=10 \mathrm{~kg} \mathrm{~S}$ and $3 \mathrm{~kg} \mathrm{~B} ; \mathrm{S}_{2} \mathrm{~B}_{0}=20 \mathrm{~kg} \mathrm{~S}$ and $0 \mathrm{~kg} \mathrm{~B} ; \mathrm{S}_{2} \mathrm{~B}_{1}=20 \mathrm{~kg} \mathrm{~S}$ and $1 \mathrm{~kg} \mathrm{~B} ; \mathrm{S}_{2} \mathrm{~B}_{2}=$ $20 \mathrm{~kg} \mathrm{~S}$ and $2 \mathrm{~kg} \mathrm{~B} ; \mathrm{S}_{2} \mathrm{~B}_{3}=20 \mathrm{~kg} \mathrm{~S}$ and $3 \mathrm{~kg} \mathrm{~B} ; \mathrm{S}_{3} \mathrm{~B}_{0}=30 \mathrm{~kg} \mathrm{~S}$ and $0 \mathrm{~kg} \mathrm{~B} ; \mathrm{S}_{3} \mathrm{~B}_{1}=30 \mathrm{~kg} \mathrm{~S}$ and $1 \mathrm{~kg} \mathrm{~B} ; \mathrm{S}_{3} \mathrm{~B}_{2}=30 \mathrm{~kg} \mathrm{~S}$ and $2 \mathrm{~kg} \mathrm{~B} ; \mathrm{S}_{3} \mathrm{~B}_{3}=30 \mathrm{~kg} \mathrm{~S}$ and $3 \mathrm{~kg} \mathrm{~B}$.

Combinations of $\mathrm{S}$ and $\mathrm{B}$ demonstrated positive effect on oil content of mustard (Table 4). The percent oil content due to different treatment combination was ranged from 41.67-44.98\%. Percent oil content gradually incraesed with the increasing of combination of $\mathrm{S}$ and $\mathrm{B}$. The highest oil content $(44.98 \%)$ was recorded from the treatment $S_{3} B_{3}\left(30 \mathrm{~kg} \mathrm{~S} \mathrm{ha}^{-1}\right.$ and $\left.3 \mathrm{~kg} \mathrm{~B} \mathrm{ha}^{-1}\right)$ followed by $S_{3} B_{2}$, $S_{3} B_{1}$ and $S_{3} B_{0}$. The lowest oil amount (41.67\%) was found in control treatment 
(Table 4).This finding was supported by Havlin et al. (1999) and Babhulkar et al.(2000). In contrast, Khatik et al. (1992) observed that S appliaction decreased the oil content. But Malewar et al. (2001) and Noor et al. (1997) reported that oil is synthesised by B nutrient with combination of other nutrient.

\section{Conclusion}

The combination of $\mathrm{S}_{2} \mathrm{~B}_{3}\left(20 \mathrm{~kg} \mathrm{~S}^{-1}\right.$ and $\left.3 \mathrm{~kg} \mathrm{~B} \mathrm{ha}^{-1}\right)$ with blanket dose of 120 $\mathrm{kg}$ urea ha- $\mathrm{h}^{-1}, 145 \mathrm{~kg}$ TSP ha-, $45 \mathrm{~kg} \mathrm{MoP} \mathrm{ha}^{-1}$ and $5 \mathrm{~kg} \mathrm{ZnSO} 4 \mathrm{ha}^{-1}$ gave higher grain yield of mustard. The treatment combination $S_{3} B_{3}\left(30 \mathrm{~kg} \mathrm{~S} \mathrm{ha}^{-1}\right.$ and $3 \mathrm{~kg} \mathrm{~B}$ $\mathrm{ha}^{-1}$ ) contributed the highest protein and oil content in mustard seed. Thus, combined application of S and B at 20 and $3 \mathrm{~kg} \mathrm{ha}^{-1}$ can be recommended for yield maximization and quality improvement of mustard in Tejgaon series soil of Madhupur Tract (AEZ 28).

\section{References}

Aulakh, M.S. and Pasricha N.S. 1997. Combined effect of S and P on growth and nutrient content of moog (Phaseolus aureus L.). Plant and Soil. 47: 141-143.

Babhulkar, P. S., Dineshkar, W. P. Badole and S. S. Balpande. 2000. Effect of Sulphur and zinc on yield, quality and nutrient uptake by safflower in vertisol. J. Ind. Soc. Soil Sci. 48(3): 541-543.

BBS (Bangladesh Bureau of Statistics). 2011. Statistical Yearbook of Bangladesh Stat. Div., Minist. Planning, Govt. Repub. of Bangladesh, Dhaka.

Brady, N.C. 1996. The nature and properties of soils. $11^{\text {th }}$ edition. McMillan Publishing Company, Ivc. New York, 444-487.

Bremner, J.M. and C.S. Mulvaney.1982. Total nitrogen, In: Methods of Soil Analysis, Part 2, $2^{\text {nd }}$ Ed., Page, A.L., Miller, R.H., Keeney, D.R., Am. Soc. Agron. Madison, USA. Pp. 599-622.

Chand, L., A.S. Sharma and S.C. Jat. 1997. Quality and uptake of nutrients in mustard as affected by foliar spray of urea and Sulphur application. Ann. Biol. Ludhiana. 13: 103-106.

Fox, R.L., R.A. Olsen and H.F. Rhoades. 1964. Evaluating the sulphur status of soil by plant and soil test. Soil Sci. Soc. Am. Proc. 28: 243-246.

FRG. 2012. Fertilizer Recommendation Guide. Published by Bangladesh Agricultural Research Council Dhaka, Bangladesh.

Ganeshamurthy, A.N. 1996. Critical plant Sulphur content and effect of S application on grain and oil yield of rainfed soybean in vertic ustochrepts. J. Indian Soc. Soil Sci. 44: 290-294.

Gomez, K.A. and Gomez A.A. 1984. Statistical Procedures for Agricultural Research. International Rice Research Institute, John Wiley \& Sons, NY.

Haq, M.O. 2012. Effect of Sulphur and Boron on seed yield of sesame (Sesamum indicum L.). MS thesis. Bangladesh Agricultural University, Mymensingh. 
Haque, M. A. 2000. Effects of Sulphur and Boron on yield, oil content and nutrient uptake of mustard. M.S. Thesis. Dept. of Soil Science, BAU, Mymensingh, 80.

Havlin, L. J., D. J. Beaton, L.S. Tisdale and L.W. Nelson. 1999. Soil Fertility and Fertilizers. Prentice Hall of Indian. $6^{\text {th }}$ edition, 220-228, 277, 319-346.

Islam, M. B. and M. A. Z. Sarker. 1993. Effect of different levels of Boron on the yield of Mustard. Research Report 1992-93. BARI, Rangpur station, 1- 4.

Islam, M. R., M. S. Islam, M. Jahiruddin and M. S. Hoque. 1999. Fffect of Sulphur, zinc and Boron on yield, yield components and nutrient uptake of wheat. Pak. J. Sci. Ind. Res. 42(3): 137-140.

Islam, M.N. 2003. Effect of Sulphur and magnesium on growth, yield, nutrient (N, P, K, $\mathrm{Ca}, \mathrm{Mg}, \mathrm{S} \& \mathrm{~B}$ ) and oil content in mustard (Brassica campestries L.) var. Tori-7. MS theis. Bangladesh Agricultural University, Mymensingh.

Jackson, M.L. 1973. Soil Chemical Analysis. Prentice Hall of India Private Limited, New Delhi. Pp. 498.

Karthikeyan, K. and L.M. Shukla. (2011). Different forms of Boron and Sulphur and their effect on B and S contents in mustard (Brassica juncea L.) and sunflower (Helianthus annus L.). Agropedology, 21(1): 28-34

Khan, M.S., M.M. Rahman, R.A. Begum, M.K. Alam, A. T. M. A. I. Mondol, M.S. Islam, and N. Salahin. 2008. Research Experiences with Problem Soils of Bangladesh (eds). Soil Science Division, Bangladesh Agricultural Research Institute (BARI), Joydebpur, Gazipur. Pp. 1-176.

Khatik, S.K., S.K. Vishwakarma and S.K. Sharma. 1992. Effect of phosphorous and Sulphur application on nutrient use efficiency and uptake by soybean in chromustert soil. J. Soils and Crops. 2: 25-29.

Malewar, G.V., S.D. Kate, S.L. Waiker and S. Ismail. 2001. Combined effect of zinc and Boron on yield, nutrient uptake and quality of mustard (Brassica juncea L.) on a Typic Haplustert. J. Indian Soc. Soil Sci. 49: 763-765.

Mohiuddin, M. 2007. Effect of nitrogen and Sulphur growth and yield of mustard (SAU Sharisha-1). MS thesis. Sher-E-Bangla Agricultural University, Dhaka-1207.

Nelson, D.W. and L.E. Sommers. 1982. Total carbon, organic carbon and organic matter. In: Methods of Soil Analysis. Part 2. $2^{\text {nd }}$ Edition. Page, A.L, Miller, R.H., Keeney, D.R. (eds), Am. Soc. of Agron. Madison, USA. Pp. 539-580.

Noor S., M.A. Hannan and M.S. Islam. 1997. Effect of molybdenum and Boron on the growth and yield of groundnut. Indian J. Agric. Res. 31: 51-58.

Olsen, S.R. and L.E. Sommers. 1982. Phosphorus. In: Methods of Soil Analysis, Part 2. $2^{\text {nd }}$ Edition. Page, A.L., Miller, R.H., Keeney, D.R. (eds), Am. Soc. Agron. Madison, USA. Pp. 403-427.

Page, A.L., R.H. Miller and D.R. Keeney (eds.). 1982. Methods of Soil Analysis. Part 2. Chemical and microbiological properties. $2^{\text {nd }}$ Edition. Agronomy series 9 ASA, SSSA. Madison Wis. USA.

Piper, C.S. 1966. Soil and Plant Analysis. Adelaide University Press, Australia. 
Pratt, P.F. 1965. Methods of Soil Analysis, Chemical and Biological properties part 2. Am. Soc. Agron. Madison, USA. P. 1023.

Robinson, R.G. 1973. Elemental Composition and Response to Nitrogen of Sunflower and Corn1. Agronomy J. 65(2).

Sarker, S.K., M.A.H. Chowdhury and H.M. Zakir. 2002. Sulphur and Boron fertilization on yield quality and nutrient uptake by Bangladesh Soybean-4. Online Journal of Biological Sciences. 2(11): 729-733.

Singh, R.N., Surendra S. and Kumar B. 2007. Combined effect of S and B on yield, nutrient uptake grown in acidic upland soil. J. Indian Soc. Soil Sci. 54(4): 516-518.

Tomer, S., T.V.S. Tomer, S. Kumer, M. Singh and S. Singh 1996. Response of Indian mustard (Brassica juncea) varieties to nitrogen, phosphorus and potassium fertilizers. Indian J. Agron. 41(4): 624-626.

Varma, S.C., R.K. Srivastava, S. Rajesh S.K. Singh, P.K. Bisen and R. Singh. 2002. Effect of varying levels of Sulphur and potassium on yield and oil content of Indian mustard (Brassica Juncea). Research on Crops. 3(3): 650-652. 